\title{
PELATIHAN PENGEMBANGAN MEDIA PEMBELAJARAN BERBASIS MULTIMEDIA UNTUK MENINGKATKAN KUALITAS DAN KREATIVITAS GURU SMA
}

\author{
Hendra Yufit Riskiawan'), Dwi Putro Sarwo Setyohadi'2), Aji Seto Arifiantoº \\ 1) 2) 3)Jurusan Teknologi Informasi, Politeknik Negeri Jember
}

\begin{abstract}
ABSTRAK
Kemajuan teknologi informasi menjadi salah satu peluang yang dapat dimanfaatkan guru dalam meningkatkan pola pembelajarannya. Banyaknya perangkat lunak yang tersedia dapat dimanfaatkan untuk mengembangkan media pembelajaran yang lebih interaktif dan menarik minat belajar para murid peserta didiknya. Fasilitas internet yang tersedia juga menjadi peluang besar untuk dapat memperkaya konten materi yang dapat disiapkan untuk disampaikan kepada peserta didiknya yang diharapkan mampu meningkatkan kualitas peserta didiknya.

Oleh karena itu diperlukan kegiatan guna meningkatkan kualitas dan kreativitas guru dalam mengembangkan media pembelajaran. Berdasarkan pemikiran tersebut maka tim pengabdian pada masyarakat mengadakan kegiatan Pelatihan Teknologi Informasi dan Pengenalan Aplikasi Komputer, dengan Tema Kegiatan: "Pelatihan Pengembangan Media Pembelajaran Berbasis Multimedia untuk Meningkatkan Kualitas dan Kreativitas Guru SMA". Melalui kegiatan ini diharapkan para guru yang ada di SMA ISLAM AL-HIDAYAH JEMBER, mampu menguasai aplikasi teknologi informasi khususnya multimedia dan memanfaatkan teknologi tersebut dalam mengembangkan media pembelajaran yang akan digunakannya.
\end{abstract}

Kata Kunci: Guru, media pembelajaran, multimedia

\section{PENDAHULUAN}

Era profesionalisme di bidang pendidikan diiringi dengan besarnya alokasi anggaran pendidikan oleh pemerintah yang salah satunya diwujudkan sebagai Tunjangan Profesi Pendidik (TPP) bagi guru, seolah menjadi pemicu bagi para guru untuk meningkatkan produktivitas dan profesionalismenya. Para guru tidak hanya dituntut untuk memenuhi beban tugas mengajar 24 jam seminggu, tetapi juga dituntut untuk lebih produktif dan meningkatkan efektivitas pola pembelajaran yang dilaksanakannya.

Kemajuan teknologi informasi menjadi salah satu peluang yang dapat dimanfaatkan guru dalam meningkatkan pola pembelajarannya. Banyaknya perangkat lunak yang tersedia dapat dimanfaatkan untuk mengembangkan media pembelajaran yang lebih interaktif dan menarik minat belajar para murid peserta didiknya. Fasilitas internet yang tersedia juga menjadi peluang besar untuk dapat memperkaya konten materi yang dapat disiapkan untuk disampaikan kepada peserta didiknya.

SMA Islam Al-Hidayah (SMAI) Jember, merupakan sekolah menengah atas yang berada di bawah naungan yayasan Ikatan Keluarga Pendidikan Islam (IKPI) Jember. Sekolah ini memiliki 25 orang guru yang terdiri dari guru tetap yayasan, guru PNS yang diperbantukan, serta Guru Tidak Tetap (GTT). Mayoritas guru yang mengajar di SMAI masih berusia muda sehingga mempunyai pengetahuan tentang komputer (computer literacy) yang cukup. Namun demikian, pemanfaatan teknologi informasi di SMAI untuk mendukung kegiatan belajar mengajar masih belum maksimal. Hal ini tergambar dari hasil observasi tim 
pengabdian masyarakat di SMAI menunjukkan bahwa fasilitas perangkat komputer yang dimiliki oleh guru-guru belum dapat dimanfaatkan secara maksimal untuk menunjang pekerjaan guru-guru terutama dalam sisi akademis.

Dampak dari belum maksimalnya pemanfaatan teknologi informasi dari sisi akademik ditunjukkan dari rendahnya produktivitas guru-guru dalam mengembangkan materi pembelajaran yang berbasis komputer dan multimedia. Metode penyampaian materi pembelajaran sebagian besar masih dilakukan secara konvensional dan monoton. Rendahnya produktivitas guru SMAI dalam menyiapkan materi pembelajaran berbasis komputer disebabkan karena kurangnya pengetahuan mengenai cara mencari informasi yang berkaitan dengan materi yang diajarkan dengan memanfaatkan teknologi informasi, serta belum familiar menggunakan tools aplikasi komputer yang ada. Sebagian besar guru SMAI kurang paham akan pemanfaatan aplikasi tersebut, sehingga berimbas pada kreativitas dan produktivitas dalam menyiapkan materi pembelajaran yang menarik dan berkualitas.

Pengembangan media pembelajaran berbasis komputer bagi guru SMAI dirasakan sangat penting, karena dapat menunjang kualitas proses belajar mengajar dan profesionalisme guru, utamanya bagi guru yang telah menerima tunjangan sertifikasi pendidik. Untuk menunjang pengembangan media pembelajaran yang lebih baik dan menarik, para guru diarahkan untuk memaksimalkan pemanfaatan teknologi informasi dan aplikasi komputer berbasis multimedia. Pemanfaatan teknologi informasi khususnya internet bertujuan untuk memperkaya konten materi yang akan disampaikan, sedangkan aplikasi presentasi dan multimedia digunakan untuk mengemas konten yang disiapkan menjadi kesatuan media pembelajaran yang menarik dan berkualitas.

Berdasarkan uraian pada analisis situasi di atas, dapat ditarik pokok permasalahan yang dihadapi oleh mitra pada SMAI Al-Hidayah Jember, meliputi beberapa permasalahan di antaranya: 1) Kurangnya pemanfaatan teknologi informasi untuk menunjang proses belajar mengajar (PBM); 2) Kurangnya pemahaman dalam pemanfaatan Teknologi Informasi untuk kepentingan pengembangan media pembelajaran, seperti pencarian informasi pada internet untuk sumber pustaka dan pengayaan konten materi pembelajaran, serta penggunaan aplikasi multimedia dan presentasi; 3) Rendahnya produktivitas guru dalam menghasilkan media pembelajaran yang menarik dan berkualitas, di mana guru SMAI Jember mengalami kendala dalam mengembangkan media pembelajaran dan menggunakan aplikasi komputer yang ada.

\section{TARGET DAN LUARAN}

Khalayak sasaran yang dilibatkan dalam Program Pengabdian kepada Masyarakat ini adalah para guru di lingkungan SMA Islam Al-Hidayah Jember.

Adapun target luaran yang diharapkan dari pelaksanaan pengabdian masyarakat ini adalah: 1) Peningkatan pengetahuan dan pemanfaatan fasilitas internet untuk menunjang pengayaan konten materi ajar guna meningkatkan kualitas proses belajar mengajar; 2) Peningkatan produktivitas dan kreativitas pengembangan media pembelajaran guru SMAI Al-Hidayah Jember; 3) Persentase jumlah media pembelajaran yang menarik dan berkualitas dari keseluruhan mata pelajaran dalam kurikulum; 4) Karya media pembelajaran berbasis multimedia yang terbaik. 


\section{METODE PELAKSANAAN}

Sebagaimana solusi yang ditawarkan, kegiatan pengabdian ini akan dilaksanakan dalam beberapa tahapan sebagai berikut:

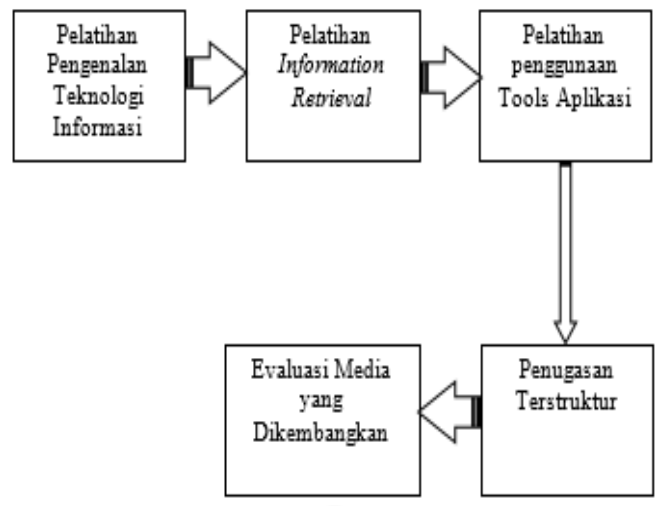

Gambar 1. Tahapan Pelaksanaan Kegiatan

Melalui pelatihan pengenalan teknologi informasi diharapkan peserta dalam hal ini guru di lingkungan SMAI Al-Hidayah Jember dapat menambah wawasan dan pengetahuan tentang perkembangan teknologi informasi, khususnya penerapan media teknologi informasi dalam menunjang pembelajaran, sehingga peserta dapat mengimplementasikan secara maksimal dalam proses belajar mengajar.

Pelatihan temu kembali informasi (Information Retrieval) dilakukan dengan pelatihan pemanfaatan media internet untuk pengayaan konten materi ajar melalui pengumpulan informasi yang akurat, kredibel dan terjamin validitasnya.

Pelatihan penggunaan tools aplikasi dapat menambah wawasan dan pengetahuan para guru untuk dapat menggunakan tools aplikasi dan multimedia yang mendukung dalam pengembangan media pembelajaran yang menarik dan berkualitas. Tools aplikasi yang akan dikenalkan penggunaannya meliputi MS Powerpoint, Macromedia Flash MX, dan Adobe Premiere.

Penugasan pembuatan media pembelajaran berbasis multimedia bagi peserta pelatihan untuk menyusun media pembelajaran sesuai dengan bidang/mata pelajaran masing-masing untuk keperluan proses belajar mengajar.

Evaluasi media pembelajaran yang dikembangkan dilakukan dengan memberi kesempatan bagi para peserta untuk berkonsultasi secara kelompok dengan narasumber mengenai konten dan media pembelajaran yang dikembangkan. Para narasumber memberi saran perbaikan agar media pembelajaran yang dihasilkan menjadi semakin berkualitas.

\section{HASIL DAN PEMBAHASAN}

Kegiatan yang dilakukan dalam pengabdian adalah dengan melakukan pelatihan yang dilakukan dalam empat kali pertemuan yaitu diawali dengan pengenalan Teknologi Informasi, Pelatihan Informasi Retrieval Pengenalan Tools Aplikasi. Dilanjutkan dengan sesi pelatihan Ms Power Point, Macromedia Flash MX, dan Adobe Premiere. Diakhiri dengan pemberian tugas terhadap peserta yang akan dibahas pada pelatihan berikutnya sebagai bahan evaluasi pemahaman materi pelatihan. Berikut ini adalah rincian tanggal pelaksanaan disajikan pada tabel 1 .

Tabel 1. Realisasi pelaksanaan pelatihan

\begin{tabular}{|l|l|l|}
\hline No & \multicolumn{1}{|c|}{ Tanggal } & \multicolumn{1}{|c|}{ Materi } \\
\hline 1 & $\begin{array}{l}27 \text { Juni } \\
2015\end{array}$ & $\begin{array}{l}\text { Pelaksanaan Pelatihan } \\
\text { Teknologi Informasi } \\
\text { dan Information } \\
\text { Retrieval }\end{array}$ \\
\hline 2 & 4 Juli 2015 & $\begin{array}{l}\text { Pelaksanaan Pelatihan } \\
\text { Pengenalan Tools } \\
\text { Aplikasi }\end{array}$ \\
\hline 3 & $\begin{array}{l}\text { 11 Juli } \\
2015\end{array}$ & $\begin{array}{l}\text { Pendampingan } \\
\text { Pelatihan Lanjutan }\end{array}$ \\
\hline 4 & $\begin{array}{l}10-14 \\
\text { Agustus } \\
2015\end{array}$ & $\begin{array}{l}\text { Pelaksanaan Evaluasi } \\
\text { Pelatihan }\end{array}$ \\
\hline
\end{tabular}


Pelaksanaan pelatihan yang pertama yaitu pelaksanaan pelatihan Teknologi Informasi dan Information Retrieval. Diberikan paparan materi pendahuluan mengenai pengenalan teknologi Informasi, yang kemudian dilanjutkan dengan Pelatihan Information Retrieval untuk membantu para guru dalam mencari dan mengumpulkan bahan untuk pengayaan materi yang akan disampaikan.

Pelaksanaan Pelatihan yang kedua yaitu pelaksanaan pelatihan pengenalan tools aplikasi Ms Power Point, Macromedia Flash MX, dan Adobe Premiere. Pelatihan ini dilakukan untuk memberikan keterampilan kepada para guru dalam mengembangkan perangkat ajarnya yang berbasis multimedia.

Pelaksanaan pelatihan yang ketiga yaitu Pendampingan Pelatihan Lanjutan. Pendampingan lanjutan ini merupakan proses pendampingan dengan membagi peserta menjadi beberapa kelompok dan setiap kelompok didampingi oleh tim pengabdi. Proses pendampingan ini dilakukan untuk mempermudah peserta memahami materi pelatihan hari pertama dan hari kedua.

Pelaksanaan pelatihan yang keempat yaitu Pelaksanaan Evaluasi Pelatihan. Proses evaluasi pelatihan dilakukan proses evaluasi terhadap pelatihan yang sudah berjalan selama tiga sesi sebelumnya, pemilihan media pembelajaran terbaik, pemberian sertifikat peserta dan penyerahan kenang-kenangan flashdisk berisi kumpulan materi pelatihan kepada pihak sekolah dan seluruh guru peserta pelatihan.

Kegiatan pengabdian pada masyarakat dilakukan pada pengajar di SMA ISLAM AL-HIDAYAH JEMBER telah berlangsung dengan baik. Hal ini terlihat dari animo guru yang mengikuti kegiatan pelatihan sangat tinggi, terbukti dengan kehadiran para guru yang mengikuti kegiatan mencapai
100\%. Hal ini mengindikasikan bahwa para guru menyambut positif kegiatan yang telah dilakukan. Sesuai dengan harapan pihak sekolah, mereka sangat mengharapkan adanya kegiatankegiatan yang sifatnya memberi penyegaran bagi para guru mengenai metode mengajar yang menyenangkan kaitannya dengan penggunaan teknologi.

Kendala-kendala yang dihadapi dalam pelaksanaan pengabdian pada masyarakat adalah terbatasnya waktu pelaksanaan yang singkat. Namun semua kendala dan masalah yang muncul telah dicarikan solusinya yaitu dengan memberikan materi sebelum pelaksanaan kegiatan sehingga harapannya peserta sudah mempersiapkan dan membaca materi, sistem diskusi selama penyampaian materi dan sistem pendampingan di akhir pelatihan. Dengan demikian kegiatan ini dapat berlangsung dengan baik.

Berdasarkan hasil evaluasi yang telah dilakukan, peserta pelatihan telah dapat memanfaatkan tool yang ada untuk membuat materi pembelajaran yang lebih menarik. Sehingga dalam penyampaian materi di kelas nantinya akan membuat siswa dapat lebih tertarik dengan materi pelajaran dari bapak/ibu guru yang telah dilatih dalam kegiatan pengabdian kepada masyarakat ini.

\section{KESIMPULAN DAN SARAN}

Hasil yang dicapai dari kegiatan pengabdian pada masyarakat adalah: a) Pengajar mampu memanfaatkan teknologi informasi khususnya internet untuk memperkaya konten materi yang akan disampaikan; b) Pengajar mampu menggunakan aplikasi presentasi dan multimedia yang digunakan untuk mengemas konten yang disiapkan menjadi kesatuan media pembelajaran yang menarik dan berkualitas; c) Pemberian kenang-kenangan kepada 
pihak sekolah berupa flashdisk yang berisi bahan materi selama pelatihan.

Berdasarkan hasil yang diperoleh dalam kegiatan pengabdian pada masyarakat ini beberapa saran yang bisa disampaikan adalah: a) pengajar agar senantiasa berupaya secara terus menerus mengembangkan kemampuan profesionalismenya; b) Ilmu yang telah didapatkan dari kegiatan ini agar dapat diterapkan di semua mata pelajaran secara berkesinambungan agar menarik siswa-siswi di sekolah.

\section{DAFTAR PUSTAKA}

Efendi, G. 2006. Pembuatan Program Aplikasi Pembelajaran Bahasa Inggris Sekolah Dasar. Politeknik Negeri. Jember

Eli. 2008. Belajar ActionScript Flash 8. http://vidyaputra.wordpress.com/ 2008/12/24/belajar-actionscriptflash-8-part-1-pendahuluan/[ 24 Desember 2008]

Gunawan, S .2008. Media Pembelajaran Pemantulan Cahaya. http://www.dikmenum.go.id/data app/e-

learning/bahan/kelas1/images/PE
MANTULAN\%20CAHAYA.pdf. [24 Desember 2008]

Hartono, J. 2010. Analisis dan Desain Sistem Informasi: Pendekatan, Terstruktur Teori, dan Praktek Aplikasi Bisnis. Yogyakarta: Andi Yogyakarta.

Nofian. 2008. Materi-Energi-Gelombang. http://www.geocities.com/no_vya nt/

Ss_inisiasi_sem1/Inisiasi_IPA_2_Edi t2.pdf. [25 Desember 2008]

Proboyekti, U, S.Kom, MLIS. Software Process Model I, dalam lecturer. ukdw.ac.id/othiesoftwareprocess.p df

Sari, D E. 2007. Proposal penelitian meningkatkan keterlibatan siswa dalam proses belajar mengajar bahasa Inggris di kelas vii smp 9. Universitas Negeri Yogyakarta

Suruali, N. 2004. Macromedia Flash MX. Institut Teknologi Bandung

Wibisono, I G. 2005. Pembuatan Program Komputer Pembelajaran Operasi Matematika Bagi Anak Sekolah Dasar Menggunakan Microsoft Visual Basic 6.0. Politeknik Negeri Jember. 